\title{
Carbon transfer from dissolved organic carbon to the cladoceran Bosmina: a mesocosm study
}

\author{
Yali Tang ${ }^{1, \mathrm{a}, *}$, Yaling $\mathrm{Su}^{2, \mathrm{a}}$, Huan $\mathrm{Sun}^{2}$, Zhengwen Liu ${ }^{1,2}$, Henri J. Dumont ${ }^{1}$, Jinrun $\mathrm{Hu}^{1}$, Yongdong \\ Zhang $^{2}$ and Jinlei $\mathrm{Yu}^{2}$ \\ ${ }^{1}$ Department of Ecology, Jinan University, Guangzhou 510632, China \\ 2 State Key Lab. of Lake and Environment, Nanjing Institute of Geography and Limnology, Nanjing 210008, China
}

\begin{abstract}
A mesocosm study illuminated possible transfer pathways for dissolved organic carbon from the water column to zooplankton. Organic carbon was added as ${ }^{13} \mathrm{C}$ enriched glucose to 15 mesocosms filled with natural lake water. Stable isotope analysis and phospholipid fatty acids-based stable isotope probing were used to trace the incorporation of ${ }^{13} \mathrm{C}$ into the cladoceran Bosmina and its potential food items. Glucose-C was shown to be assimilated into phytoplankton (including fungi and heterotrophic protists), bacteria and Bosmina, all of which became enriched with ${ }^{13} \mathrm{C}$ during the experiment. The study suggests that bacteria play an important role in the transfer of glucose-C to Bosmina. Furthermore, osmotic algae, fungi and heterotrophic protists might also contribute to the isotopic signature changes observed in Bosmina. These findings help to clarify the contribution of dissolved organic carbon to zooplankton and its potential pathways.
\end{abstract}

\begin{abstract}
Keywords: t-DOC / bacteria / Bosmina / PLFA-SIP
Résumé - Transfert de carbone du carbone organique dissous au cladocère Bosmina : une étude en mésocosmes. Une étude de mésocosmes a permis d'éclairer les voies de transfert possibles pour le carbone organique dissous de la colonne d'eau au zooplancton. Le carbone organique a été ajouté sous forme de glucose enrichi en ${ }^{13} \mathrm{C}$ à 15 mésocosmes remplis d'eau naturelle du lac. Une analyse d'isotope stable et un marqueur isotopique stable à base de phospholipides ont été utilisés pour tracer l'incorporation du ${ }^{13} \mathrm{C}$ dans le cladocère Bosmina et ses sources alimentaires potentielles. On a montré que le glucose-C était assimilé dans le phytoplancton (y compris les champignons et les protistes hétérotrophes), les bactéries et Bosmina, qui ont tous été enrichis en ${ }^{13} \mathrm{C}$ pendant l'expérience. L'étude suggère que les bactéries jouent un rôle important dans le transfert du glucose-C à Bosmina. En outre, les algues, les champignons et les protistes hétérotrophes pourraient également contribuer aux changements de signature isotopique observés chez Bosmina. Ces résultats permettent de clarifier la contribution du carbone organique dissous au zooplancton et ses voies potentielles.
\end{abstract}

Mots-clés : t-DOC / bactérie / Bosmina / PLFA-SIP

As a constituent of organic carbon content of lakes, terrestrial dissolved organic carbon (t-DOC) has significant ecological effects on food webs by serving as a substrate for heterotrophic metabolism (Tranvik, 1998; Karlsson et al., 2003; Solomon et al., 2015). Despite evidence of terrestrial support for secondary production in lakes (Berggren et al., 2010a,b; Tanentzap et al., 2015), the transfer of t-DOC to higher trophic levels remains contentious (Ducklow et al., 1986; Brett et al., 2012; Kelly et al., 2016).

\footnotetext{
${ }^{a}$ These authors contributed equally to this paper.

* Corresponding author: litangyali@163.com
}

Previous studies have used mesocosms with artificial t-DOC additions to address whether t-DOC affects zooplankton. Most published studies report zooplankton density increases after t-DOC input (Faithful et al., 2011; Cooke et al., 2015; Geddes, 2015). However, Kelly et al. (2016) suggested that it is the increase t-DOC-associated phosphorus, rather than t-DOC itself that boosts phytoplankton growth and ultimately causes zooplankton density increases. Others have confirmed zooplankton assimilation of t-DOC based on the natural abundance of stable carbon isotopes $\left(\delta^{13} \mathrm{C}\right)$ as a tracer (Karlsson et al., 2007; Hitchcock et al., 2016). Yet sometimes question exists when differences in $\delta^{13} \mathrm{C}$ between terrestrial 
and aquatic primary producers are too small to distinguish by this technique.

Major concern of t-DOC transfer to zooplankton centers on food quality (Brett et al., 2012; Taipale et al., 2014). Bacteria grown on t-DOC lack some biochemicals essential for the growth and reproduction of consumers (e.g. highly-unsaturated fatty acids, HUFA), and have thus been deemed unsuitable as a sole food source (Martin-Creuzburg et al., 2011). However, mixed algae-bacteria diet can support the growth and reproduction of zooplankton (Wenzel et al., 2012). Besides, microbial food for zooplankton consists of additional heterotrophic microbes in addition to bacteria, e.g. fungi and bactivorous protists (Sherr and Sherr, 1994; Rösel et al., 2012). Their ability of HUFA synthesis was previously reported (Hauvermale et al., 2006; Chu et al., 2008). So, we hypothesized that heterotrophic microbes may play important roles in transferring t-DOC to zooplankton.

To test our hypothesis, we traced the fate of ${ }^{13} \mathrm{C}$ enriched glucose added to 15 aquatic mesocosms during June to July, 2013. Similar-sized microbes like algae and bacteria being difficult separated for sampling could be distinguished by PLFA (phospholipid fatty acids), for which specific microbial groups produce signature PLFA profiles (Boschker and Middelburg, 2002). Moreover, microbial PLFA and wholecell share similar isotopic signatures (De Kluijver et al., 2015). Hence carbon stable isotopic analysis of their signature PLFA can be used to study the source of carbon they assimilated (PLFA-based stable isotope probing, PLFA-SIP), and is applied in our experiment.

Each mesocosm contained $100 \mathrm{~L}$ surface water from the shore of Fuxian Lake in China $\left(24^{\circ} 21^{\prime} 28^{\prime \prime}-24^{\circ} 38^{\prime} 00^{\prime \prime} \mathrm{N}\right.$, $\left.102^{\circ} 49^{\prime} 12^{\prime \prime}-102^{\circ} 57^{\prime} 26^{\prime \prime} \mathrm{E}\right)$. Fuxian Lake with an area of $211 \mathrm{~km}^{2}$, is a deep oligotrophic lake with low phosphorus content, while with macrophyte in shores. After setting up, 3 mesocosms were sampled to provide reference values (T0). $30 \mathrm{mg}{ }^{13} \mathrm{C}$-glucose was then added to rest 12 mesocosms, and each three mesocosms were sampled on days 1, 3, 6 and 9 during the experiment (T1, T3, T6 and T9 respectively). Each mesocosm was sampled only once. Total nitrogen (TN), total phosphorus (TP) and Chlorophyll $a(\mathrm{Chl} a)$ concentrations of mesocosm water were measured as previously described (Zhang et al., 2016). DOM (dissolve organic matter) concentrations were analyzed using a TOC analyzer (Shimadzu TOC-L CPH CN200, Japan).

Both particulate organic matter (POM) and microbial samples were gathered by filtering $2-5 \mathrm{~L}$ water through Whatman (GF-F) glass-fiber filters (pore size $0.7 \mu \mathrm{m}$ ). Water after filtration was dried $48^{\circ} \mathrm{C}$ to form DOM samples. Zooplankton was collected from the mesocosms using a $64 \mu \mathrm{m}$ mesh-size net. The dominant species in all mesocosms, Bosmina sp., was picked out. POM and Bosmina samples were dried also at $48^{\circ} \mathrm{C}$ and subjected to carbon isotopic analysis by carrying on an EA 1112 elemental analyzer coupled to an isotope ratio mass spectrometer (Thermo Finnigan Delta V) together with DOM samples. Phospholipid fatty acids of microbial samples were extracted according to Guckert et al. (1985). $\delta^{13} \mathrm{C}$ of single PLFA was detected by a GC-c-IRMS (Thermo Finnigan, Germany). Isotopic analysis was conducted in Key Laboratory of Global Change and Marine-Atmospheric Chemistry, State Oceanic Administration, China. Based on sample replicates, the analytical precision was $0.3 \%$ for $\delta^{13} \mathrm{C}$.
The concentration-weighted $\delta^{13} \mathrm{C}$ of branched fatty acids i15:0 and ai15:0 were used to symbolize bacterial $\delta^{13} \mathrm{C}$ $\left(\delta^{13} C_{\text {bacteria }}\right)$ according to Boschker and Middelburg (2002). $\delta^{13} \mathrm{C}$ of phytoplankton $\left(\delta^{13} \mathrm{C}_{\text {phytoplankton }}\right)$ was calculated as concentration-weighted $\delta^{13} \mathrm{C}$ of polyunsaturated fatty acids

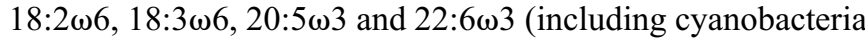
and eukaryotic algae), as recommended by De Kluijver et al.

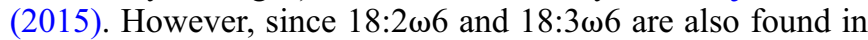
fungi (Wurzbacher et al., 2010), fungi must be considered as potential contributors to the observed phytoplankton isotopic signatures. One-way ANOVA and repeated measures ANOVA were conducted to compare stable isotopic signatures in different mesocosms and between different organisms respectively in SPSS 18.0. Correlation analysis used Pearson Correlation also in SPSS. Key physiochemical information of mesocosms is given in Table 1. All stable isotopic signatures are shown in Figure 1.

${ }^{13} \mathrm{C}_{\text {bacteria }}$ values started at averaged $-23.1 \%$. Subsequently, a significant increase in $\delta^{13} C_{\text {bacteria }}$ was observed on day 1 samples $(P<0.05)$, consistent with massive t-DOC support for bacterial production (Cole et al., 2006). In following days, however, $\delta^{13} \mathrm{C}_{\text {bacteria }}$ fell rapidly. Quickly use up of labile glucose and following more incorporation of depleted DOM into bacterial biomass is a potential factor in decline of

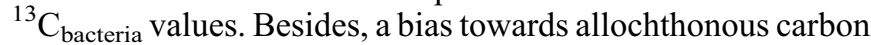
in bacterial respiration reported (Karlsson and Jonsson, 2007) probably contributes to this rapid decrease of $\delta^{13} \mathrm{C}_{\text {bacteria }}$.

Particulate organic matter comprises a mixture of bacteria, phytoplankton, detrital aggregates and other material, with an initial average $\delta^{13} \mathrm{C}_{\mathrm{POM}}$ of $-14 \%$. $\delta^{13} \mathrm{C}_{\mathrm{POM}}$ was closely correlated to $\delta^{13} \mathrm{C}_{\text {bacteria }}(r=0.984, P<0.001)$ and changes in $\delta^{13} \mathrm{C}_{\mathrm{POM}}$ recorded in the mesocosms were consistent with $\delta^{13} \mathrm{C}_{\text {bacteria. In experiments designed to record microbial }}$ uptake of ${ }^{3} \mathrm{H}$-labeled glucose and acetate, Paerl (1974) concluded that radioactive isotopic signature could be passed to POM by bacterial uptake and their help in the formation of detrital aggregates.

$\delta^{13} \mathrm{C}_{\mathrm{DOM}}$ of $-14.8 \%$ in $\mathrm{T} 0$ mesocosm was observed to increase by a relatively small amount on the first day and increased gradually in following days, indicating that ${ }^{13} \mathrm{C}$ glucose supplement was exhausted in the very first day. ${ }^{13} \mathrm{C}_{\mathrm{DOM}}$ values that persist later in the experiment are likely due to excretion by bacteria and zooplankton.

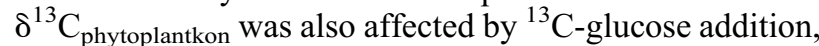
increasing from $-26.3 \%$ on average to a maximum of $222.6 \%$. There are three plausible explanations for this observed increase. Firstly, the inclusion of heterotrophic fungi, which can be supported by extra organic carbon, e.g. t-DOC (Rösel et al., 2012). Second, the presence of mixotrophic and heterotrophic protists by grazing on bacteria or osmosis as well as osmotrophic algae, which are able to assimilate DOC and synthesize HUFA (Jones, 2000; Tittel et al., 2009). A third possibility is that dissolved inorganic carbon (DIC) could be derived from respiration of non-autochthonous carbon (Karlsson and Jonsson, 2007), possibly supporting the growth of autotrophic phytoplankton. Since all these fungi, mixotrophic and heterotrophic protists, as well as algae are available as potential food for zooplankton, they offer a variety of trophic transfer pathway for glucose-C into zooplankton.

A significant increase in $\delta^{13} \mathrm{C}_{\text {zooplankton was also observed }}$ after glucose addition $(P<0.05)$, and $\delta{ }^{13} C_{\text {zooplankton values }}$ 


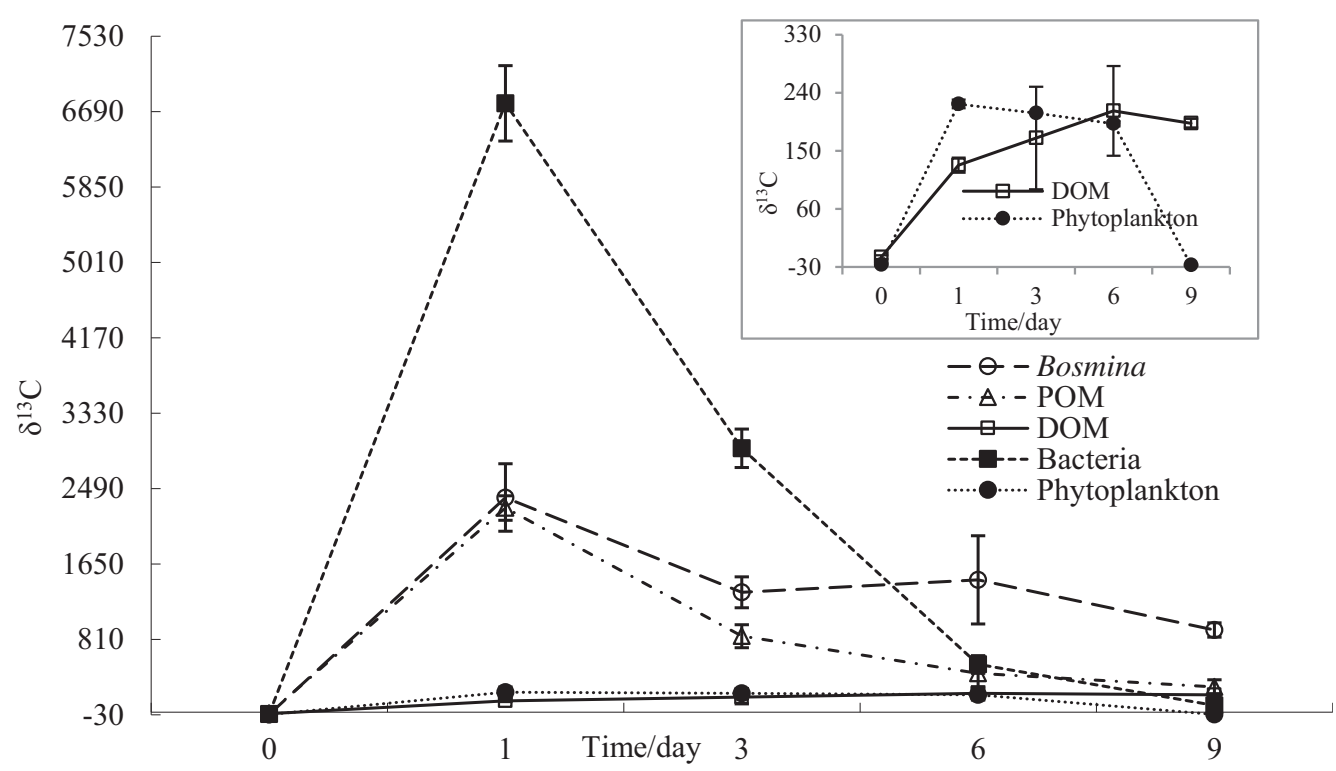

Fig. 1. Carbon stable isotope signatures of bacteria (indicated by PLFA), POM, DOM, phytoplankton (indicated by PLFA) and Bosmina in mesocosms after $0 \mathrm{~d}, 1 \mathrm{~d}, 3 \mathrm{~d}, 6 \mathrm{~d}, 9 \mathrm{~d}$ incubation with ${ }^{13} \mathrm{C}$-glucose (mean $\pm \mathrm{SD}$ ).

Table 1. Physiochemical information of experimental groups. Note: Values given in average and - indicates not detected.

\begin{tabular}{lllllll}
\hline No & Sampling date & TN $(\mathrm{mg} / \mathrm{L})$ & TP $(\mathrm{mg} / \mathrm{L})$ & Chl $a(\mu \mathrm{g} / \mathrm{L})$ & DOM $(\mathrm{mg} / \mathrm{L})$ & Bosmina predator \\
\hline T0 & June 29 & 0.34 & 0.007 & 5.3 & 1.399 & - \\
T1 & June 30 & 0.34 & 0.015 & 7.2 & 1.360 & - \\
T3 & July 2 & 0.43 & 0.020 & 9.7 & 1.542 & - \\
T6 & July 5 & 0.31 & 0.013 & 3.8 & 1.646 & - \\
T9 & July 8 & 0.38 & 0.013 & 4.7 & 1.899 & - \\
\hline
\end{tabular}

remained significantly higher than those of phytoplankton thereafter $(P<0.05)$. These results confirmed the rapid assimilation of glucose-C by Bosmina. $\delta^{13} C_{\text {zooplankton was }}$ substantially higher than $\delta^{13} \mathrm{C}_{\mathrm{POM}}$ after glucose addition $(P<0.05)$ indicating that Bosmina had utilized an isotopically heavier food source than the analyzed POM fraction. Only bacteria were isotopically heavier than POM, suggesting selective consumption of bacteria by Bosmina. Freese and Martin-Creuzburg (2013) found that Daphnia magna grew better with a mixed bacteria-algae diet than sole algae, possibly due to bacteria-derived nutrients, e.g. vitamins, which could also explain our results.

In summary, our mesocosm experiments confirm the rapid incorporation of glucose-C by Bosmina. The results provide evidence for a transfer of carbon by direct consumption of bacteria. Besides, fungi, mixotrophic and heterotrophic protists as well as algae offer further likely pathways whereby from glucose-C may be assimilated by zooplankton. To be noticed, t-DOC is a more recalcitrant carbon than labile glucose. However, Berggren et al. (2010a) and Attermeyer et al. (2014) reported t-DOC to include some low molecular weight substances labile to bacteria thus similar to glucose. Considering that labile part of t-DOC has an unproportionally large impact on aquatic secondary production compared its share of total t-DOC (Berggren et al., 2010b), this experiment hints at possible transfer pathways for DOC included t-DOC into zooplankton.

Acknowledgement. This study was financially supported by National Natural Science Foundation of China (Nos. 31370478, 31000219, 41471086 and U1033602).

\section{References}

Attermeyer K, Hornick T, Kayler ZE, et al. 2014. Enhanced bacterial decomposition with increasing addition of autochthonous to allochthonous carbon without any effect on bacterial community composition. Biogeosciences 11(6): 1479-1489.

Berggren M, Laudon H, Haei M, Strom L, Jansson M. 2010a. Efficient aquatic bacterial metabolism of dissolved low-molecularweight compounds from terrestrial sources. ISME J 3: 408-416.

Berggren M, Ström L, Laudon H, et al. 2010b. Lake secondary production fueled by rapid transfer of low molecular weight organic carbon from terrestrial sources to aquatic consumers. Ecol Lett 13(7): 870-880.

Boschker HTS, Middelburg JJ. 2002. Stable isotopes and biomarkers in microbial ecology. FEMS Microbiol Ecol 40(2): 85-95.

Brett MT, Arhonditsis GB, Chandra S, Kainz MJ. 2012. Mass flux calculations show strong allochthonous support of freshwater zooplankton production is unlikely. PLOS ONE 7(6): e39508. 
Chu F-LE, Lund ED, Podbesek JA. 2008. Quantitative significance of n-3 essential fatty acid contribution by heterotrophic protists in marine pelagic food webs. Mar Ecol Prog Ser 354: 85-95.

Cole JJ, Carpenter SR, Pace ML, et al. 2006. Differential support of lake food webs by three types of terrestrial organic carbon. Ecol Lett 9(5): 558-568.

Cooke SL, Fischer JM, Kessler K, et al. 2015. Direct and indirect effects of additions of chromophoric dissolved organic matter on zooplankton during large-scale mesocosm experiments in an oligotrophic lake. Freshw Biol 60(11): 2362-2378.

De Kluijver A, Ning J, Liu Z, Jeppesen E, Gulati RD, Middelburg JJ. 2015. Macrophytes and periphyton carbon subsidies to bacterioplankton and zooplankton in a shallow eutrophic lake in tropical China. Limnol Oceanogr 60: 375-385.

Ducklow HW, Purdie DA, Williams PJL, Davies JM. 1986. Bacterioplankton - a sink for carbon in a coastal marine plankton community. Science 232: 865-867.

Faithful CL, Huss M, Vrede T, Bergström AK. 2011. Bottom-up carbon subsidies and top-down predation pressure interact to affect aquatic food web structure. Oikos 120: 311-320.

Freese HM, Martin-Creuzburg D. 2013. Food quality of mixed bacteriaalgae diets for Daphnia Magna. Hydrobiologia 715: 63-76.

Geddes P. 2015. Experimental evidence that subsidy quality affects the temporal variability of recipient zooplankton communities. Aquat Sci 77: 609-621.

Guckert JB, Antworth CP, Nichols PD, White DC. 1985. Phospholipid ester-linked fatty acid profiles as reproducible assays for changes in prokaryotic community structure of estuarine sediments. FEMS Microbiol Ecol 31: 147-158.

Hauvermale A, Kuner J, Rosenzweig B, Guerra D, Diltz S, Metz JG. 2006. Fatty acid production in Schizochytrium sp.: involvement of a polyunsaturated fatty acid synthase and a type 1 fatty acid synthase. Lipids 41: 739-747.

Hitchcock, JN, Mitrovic SM, Hadwen WL, et al. 2016. Terrestrial dissolved organic carbon subsidizes estuarine zooplankton: an in situ mesocosm study. Limnol Oceanogr 61(1): 254-267.

Jones RI. 2000. Mixotrophy in planktonic protists: an overview. Freshw Biol 45(2): 219-226.

Karlsson J, Jonsson A. 2007. Respiration of allochthonous organic carbon in unproductive forest lakes determined by the keeling plot method. Limnol Oceanogr 52(2): 603-608.

Karlsson J, Jonsson A, Meili M, Jansson M. 2003. Control of zooplankton dependence on allochthonous organic carbon in humic and clear-water lakes in northern Sweden. Limnol Oceanogr 48: 269-276.
Karlsson J, Lymer D, Vrede K, Jansson M. 2007. Differences in efficiency of carbon transfer from dissolved organic carbon to two zooplankton groups: an enclosure experiment in an oligotrophic lake. Aquat Sci 69(1): 108-114.

Kelly P, Craig N, Solomon CT, Weidel BC, Zwart JA, Jones S. 2016. Experimental whole-lake increase of dissolved organic carbon concentration produces unexpected increase in crustacean zooplankton density. Global Change Biol 22(8): 2766-2775.

Martin-Creuzburg D, Beck B, Freese HM. 2011. Food quality of heterotrophic bacteria for Daphnia magna: evidence for a limitation by sterols. FEMS Microbiol Ecol 76: 592-601.

Paerl HW. 1974. Bacterial uptake of dissolved organic matter in relation to detrital aggregation in marine and freshwater systems. Limnol Oceanogr 19(6): 966-972.

Rösel S, Rychla A, Wurzbacher C, Grossart H-P. 2012. Effects of pollen leaching and microbial degradation on organic carbon and nutrient availability in lake water. Aquat Sci 74: 87-99.

Sherr EB, Sherr BF. 1994. Bacterivory and herbivory: key roles of phagotrophic protists in pelagic food webs. Microb Ecol 28(2): 223-235.

Solomon CT, Jones SE, Weidel BC, et al. 2015. Ecosystem of changing inputs of terrestrial dissolved organic matter to lakes: current knowledge and future changes. Ecosystems 18: 376-389.

Taipale SJ, Brett MT, Hahn MW, et al. 2014. Differing Daphnia magna assimilation efficiencies for terrestrial, bacterial, and algal carbon and fatty acids. Ecology 95(2): 563-576.

Tanentzap AJ, Szkokan-Emilson EJ, Kielstra BW, Arts MT, Yan ND, Gunn JM. 2015. Forests fuel fish growth in freshwater deltas. Nat Commun 5: 4077.

Tittel J, Wiehle I, Wannicke N, Kampe H, Poerschmann J, Meier J. 2009. Utilisation of terrestrial carbon by osmotrophic algae. Aquat Sci 71(1): 46-54.

Tranvik LJ. 1998. Degradation of dissolved organic matter in humic waters by bacteria. In: Hessen DO, Tranvik LJ, eds. Aquatic humic substances. New York: Springer-Verlag, pp. 259-283.

Wenzel A, Bergström A-K, Jansson M, Vrede T. 2012. Survival, growth and reproduction of Daphnia galeata feeding on single and mixed Pseudomonas and Rhodomonas diets. Freshw Biol 57: 835-846.

Wurzbacher CM, Bärlocher F, Grossart H-P. 2010. Fungi in lake ecosystems. Aquat Microb Ecol 59:125-149.

Zhang X, Tang Y, Jeppesen E, Liu Z. 2016. Biomanipulation-induced reduction of sediment phosphorus in a tropical shallow lake. Hydrobiologia, doi:10.1007/s10750-016-3079-x.

Cite this article as: Tang Y, Su Y, Sun H, Liu Z, Dumont HJ, Hu J, Zhang Y, Yu J. 2017. Carbon transfer from dissolved organic carbon to the cladoceran Bosmina: a mesocosm study. Knowl. Manag. Aquat. Ecosyst., 418, 24. 